\title{
Predictors of Malignancy in Patients With Thyroid Nodule(s)
}

\author{
Preditores de malignidade em pacientes com nódulo(s) de tireoide
}

Islam Alatiar, Hassam Elfol, Tarek Rageh

Study performed at Faculty of Medicine, Menoufia University, Egypt.

Financial support: none.

Conflict of interest: None.

Correspondence address: Dr. Islam Alatiar, dr.islamalatiar@yahoo.com

Submitted: July 9, 2017. Accepted, after review: August 4, 2017.

\section{ABSTRACT}

Purpose: To detect the predictors of malignancy in patients with thyroid nodule(s). Background: Thyroid nodules are common surgical problem with $5-10 \%$ risk of malignancy. Thyroid surgery is a major operation with many complications. So, it is important to search for the predictors of malignancy in thyroid nodules to spare more benign lesions from surgery. Patients and methods: This prospective study includes 150 patients with thyroid nodule(s), all were admitted for thyroidectomy at Menoufia University Hospital. Demographic and clinical data, ultrasound, fine needle aspiration reports and final histopathology were recorded and analyzed. Patients with previous thyroid surgery or previous neck biopsy were excluded. Results: About $20 \%$ of the studied population proved to have malignant nodules on final histopathology reports. Out of 150 cases, there were 83 with multi-nodular goiter and 67 with solitary thyroid nodules. There were higher incidence of malignancy in male patients. The incidence also was higher in solitary nodules than in multinodular goiter. There were statistically significant ultrasound features differences such as; micro-calcifications, ill-defined edges, solid consistency, hypo-echoic pattern, intra-nodular vascularity and size below $2 \mathrm{~cm}$. Regarding fine needle biopsy, there were a significant increase in incidence of malignancy from Bethesda(II) - Bethesda(VI) with highest incidence in Bethesda(VI). Conclusion: Predictors of malignancy detected were; male gender, solitary nodules, micro-calcifications, hypo-echoic pattern, ill-defined edges, intra-nodular vascularity, solid nodules, size below $2 \mathrm{~cm}$ and Bethesda VI. Large scale multi center studies are needed for more solid statistical result.

Key words: Goiter, nodular. Malignancy. Multinodular goiter. Nodules, solitary. Ultrasound. 
RESUMO

Objetivo: Os nódulos da tireóide são problemas cirúrgicos comuns com 5-10\% de risco de malignidade. A cirurgia de tireóide é uma operação importante com muitas complicações. Por isso, é importante pesquisar os preditores de malignidade em nódulos tireoidianos para poupar lesões benignas da cirurgia. O objetivo do presente estudo foi detectar os preditores de malignidade em pacientes com nódulo ( $\mathrm{s}$ ) tireoidiano (s). Métodos: Este estudo prospectivo inclui 150 pacientes com nódulo (s) de tireoide. Todos foram admitidos para tireoidectomia no Hospital Universitário Menoufia. Foram registrados e analisados dados demográficos e clínicos, ultra-som, relatórios de biópsia por aspiração com agulhas finas e histopatologia final. Pacientes com cirurgia anterior de tireóide ou biópsia anterior no pescoço foram excluídos. Resultados: Cerca de $20 \%$ da população estudada provou ter nódulos malignos em relatórios de histopatologia final. Dos 150 casos, havia 83 com bócio multi-nodular e 67 com nódulos de tireóide solitários. Houve maior prevalência de malignidade em pacientes do sexo masculino. A prevalência também foi maior nos nódulos solitários do que no bócio multinodular. Havia diferenças de características de ultrassom estatisticamente significativas, tais como: microcalcificações, bordas mal definidas, consistência sólida, padrão hipoecoico, vascularização intra-nodular e tamanho inferior a $2 \mathrm{~cm}$. Em relação à biópsia com agulha fina, houve aumento significativo da incidência de malignidade Bethesda (II) - Bethesda (VI) com maior incidência em Bethesda (VI). Conclusão: os preditores de malignidade detectada foram: gênero masculino, nódulos solitários, microcalcificações, padrão hipoecoico, bordas mal definidas, vascularização intra-nodular, nódulos sólidos, tamanho inferior a $2 \mathrm{~cm}$ e Bethesda VI. Estudos multicentros de grande escala são necessários para um resultado estatístico mais sólido.

Descritores: Bócio. Neoplasias. Nódulos. Solitário. Ultrassom.

\section{INTRODUCTION}

Thyroid nodules are defined as any abnormal growth causing mass in thyroid tissue $^{1}$. Thyroid nodules can be found in $4 \%$ to $8 \%$ by palpation and in $10 \%$ to $40 \%$ by ultrasound study ${ }^{2}$. Thyroid cancer is more common than all other endocrine cancers with increasing incidence worldwide ${ }^{3,4}$. The most prevalent types of thyroid malignancies are the differentiated types, papillary and follicular malignancies ${ }^{1}$. Clinically there are simple characteristics that are known to be risky regarding malignancy including male sex, age below 30 y and above $60 y$, family history of previous thyroid malignancy, previous exposure to neck irradiation and a hard nodule that may cause compression symptoms5. Being noninvasive and inexpensive tool, the ultrasound became the most frequently used imaging test in evaluating the thyroid gland ${ }^{6,7}$. In addition to clinical assessment, ultrasound helps 
to identify risky nodules with risky criteria like micro-calcifications, hypo-echoic pattern, illdefined edged nodules and solid pattern ${ }^{8}$. Nowadays, fine needle aspiration biopsy (FNAB) is considered as the gold standard for diagnosis of thyroid malignancy, but unfortunately about $25 \%$ of its biopsies are non-diagnostic ${ }^{9}$. Recently, Thyroid stimulating hormone (TSH) is considered as a predictor of malignancy in thyroid nodules in many studies. Studies reported a relation between TSH and malignancy as the TSH promotes thyroid cells proliferation $^{10,11}$.

Most studies focused on single risks predicting the incidence of thyroid malignancy which is not satisfactory, so our study aims to detect different predictors together using clinical, laboratory and radiological assessment.

\section{PATIENTS AND METHODS}

This prospective study was carried on at the department of surgery, Faculty of Medicine, Menoufia University on 150 patients suffering from thyroid nodule(s), after obtaining an informed consent from all patients. We excluded all patients with previous surgery of thyroid cancer and those with previous cervical lymph node biopsy. All patients were evaluated in regards to full clinical assessment: (history, physical examination). Laboratory data: in the form of Thyroid stimulating hormone(TSH), Tri-iodo-thyronin(T3), Thyroxine(T4) using Vidas 30- Biomerieux- United States of America. Imaging data were done on a Philips iU22 ultrasound (US) machine, with a high frequency 7.5-10 MHs probe, color and power Doppler of frequency 4-7 MHs. The solitary and the largest nodule in case of MNG were evaluated by ultrasound, the following criteria were included; number, maximum diameter of the nodule, calcifications (micro-macro), echogenicity, margins (ill defined-well defined), consistency (solid, cystic, mixed), vascularity and suspicious lymph nodes. All patients underwent FNAC and then were classified according to the Bethesda system into BI, BII, BIII, BIV, BV, BVI. All patients underwent surgery (total, subtotal and lobectomy) then the final pathology reports were analyzed. Approval to undertake the study was received from the Menoufia Research and Ethics committee. 


\section{Statistical analysis}

Data were collected in tables then analyzed in regarding to Chi square $(\chi 2)$ and $p$ value. $P$ values less than 0.05 were considered significant.

\section{RESULTS}

Out of 150 patients included in our study there were 122 females and 28 males. The mean age of females was 41 years and for males was 38 combining age to gender in different age groups there was no significant difference (Table1). Multi-nodular goiter detected in 83(55.3\%) patients and solitary thyroid nodules in 67 (44.7\%) patients. Out of 150 patients included in this study there were 120 (80\%) patients with benign nodules and $30(20 \%)$ patients with malignant nodules. In case of female patients there were 20 (16.4\%) patients with malignant nodules and $102(83.6 \%)$ patients with benign nodules but in males there were 10 (35.8\%) patients with malignant nodules and 18 (64.3\%) with benign nodules with significant difference between both $\left(\chi^{2} 5.313, P\right.$ value $\left.=0.021\right)$. In case of solitary thyroid nodules there were $47(70 \%)$ of patients with benign nodules and $20(30 \%)$ patients with malignant nodules however, in case of multi-nodular goiter there were 73 (88\%) patients with benign nodules and $10(12 \%)$ patients with malignant nodules with significant difference between both and higher incidence of malignancy in solitary nodules $\left(\chi^{2}=7.344\right.$, $\mathrm{P}=0.004)$. The majority of patients $(94.1 \%)$ presented with neck swelling with/without other symptoms like dyspnea and dysphagia with no statistical importance. Hoarseness of voice wasn't recorded in any case. Smoking was detected in 13 cases all of them are males with 10 patients had benign nodules and 3 patients had malignant nodules with no statistically important value $\left(\chi^{2}=0.084, P=0.772\right)$. Two cases only reported a family history of previous exposure to irradiation to the head and neck, one had malignancy and the other had benign nodules with non-significant value $(P=0.56)$. Regarding TSH levels there was no significant difference between benign and malignant nodules $(p=0.722)$. There are statistically significant ultrasound data shown in (table 3) predicting malignancy such as micro calcification $(P=0.002)$, ill-defined edges $(P=0.0003)$, increased intra-nodular vascularity $(P=0.003)$, size below $2 \mathrm{~cm}(P=0.002)$, solid consistency $(P=0.002)$, hypoechogenicity $(P=0.004)$. Regarding FNAC there were 5 patients in Bethesda(I) all were 
benign, 90 patients in Bethesda (II) with 89 benign and one malignant, 18 in Bethesda(III) with 16 of them were reported as benign and 2 as malignant, 9 in Bethesda( IV) with 6 of them had benign nodules and 3 had malignant nodules, 7 in Bethesda (V) with 2 had benign nodules and 5 had malignant nodules and in Bethesda (VI) there were 21 patients 2 (9.5\%) of them had benign nodules and 19 (90.5\%) had malignant nodules. The incidence of malignancy increases from $\mathrm{B}(\mathrm{II})-\mathrm{B}(\mathrm{VI})$ with the greatest incidence in (BVI) which is a good predictor of malignancy $\left(\chi^{2}=99.97, \mathrm{P}<0.0001\right)$. The results are summarized in tables 2,3 and 4.

Table 1 - Age and sex distribution for malignancy.

\begin{tabular}{lccccc}
\hline \multirow{2}{*}{ Age in years } & \multicolumn{2}{c}{ Benign $\mathrm{N}=120$} & Malignant & $\mathrm{N}=30$ & \\
\cline { 2 - 5 } & $\begin{array}{c}\text { Female } \\
\mathrm{N}=96\end{array}$ & $\begin{array}{c}\text { Male } \\
\mathrm{N}=24\end{array}$ & $\begin{array}{c}\text { Female } \\
\mathrm{N}=25\end{array}$ & $\begin{array}{c}\text { Male } \\
\mathrm{N}=5\end{array}$ & p-value \\
\hline$<30$ & 16 & 4 & 4 & 0 & 0.333 \\
$30-40$ & 38 & 11 & 8 & 3 & 0.313 \\
$41-50$ & 22 & 7 & 8 & 2 & 0.361 \\
$51-60$ & 14 & 2 & 3 & 0 & 0.404 \\
$>60$ & 6 & 0 & 2 & 0 & 0.592 \\
\hline
\end{tabular}

Table 2 - Clinical data in patients with benign and malignant nodules.

\begin{tabular}{|c|c|c|c|c|c|c|}
\hline & \multicolumn{4}{|c|}{ Histopathology } & \multirow{3}{*}{$\chi^{2}$} & \multirow{3}{*}{$p$-value } \\
\hline & \multicolumn{2}{|c|}{ Benign } & \multicolumn{2}{|c|}{ Malignant } & & \\
\hline & $\mathrm{N}$ & $\%$ & $\mathrm{~N}$ & $\%$ & & \\
\hline Cosmetic disfigurement & 113 & 94.2 & 27 & 90.0 & 0.670 & 0.413 \\
\hline Dyspnea & 3 & 2.5 & 0 & 0.0 & 0.765 & 0.382 \\
\hline Dysphagia & 10 & 8.3 & 0 & 0.0 & 2.679 & 0.102 \\
\hline Voice hoarseness & 0 & 0.0 & 0 & 0.0 & - & - \\
\hline History Irradiation exposure & 2 & 1.7 & 1 & 3.3 & 0.340 & 0.560 \\
\hline Family history of Thyroid neoplasm & 1 & 0.8 & 1 & 3.3 & 1.140 & 0.286 \\
\hline Smoking & 10 & 8.3 & 3 & 10.0 & 0.084 & 0.772 \\
\hline
\end{tabular}

$\chi^{2}-$ Chi square test 
Table 3 - Ultrasound features in benign and malignant nodules.

\begin{tabular}{|c|c|c|c|c|c|c|}
\hline \multirow{2}{*}{ Ultrasound Features } & \multicolumn{2}{|c|}{ Benign } & \multicolumn{2}{|c|}{ Malignant } & \multirow{2}{*}{$\chi^{2}$} & \multirow{2}{*}{$p$-value } \\
\hline & $\mathrm{N}$ & $\%$ & $\mathrm{~N}$ & $\%$ & & \\
\hline \multicolumn{7}{|l|}{ Number } \\
\hline Solitary & 47 & 70.1 & 20 & 29.9 & \multirow{2}{*}{7.344} & \multirow{2}{*}{0.004} \\
\hline Multinodular & 73 & 87.9 & 10 & 12.1 & & \\
\hline \multicolumn{7}{|l|}{ Consistency } \\
\hline Solid & 39 & 66.1 & 20 & 33.9 & \multirow{3}{*}{11.29} & \multirow{3}{*}{0.0025} \\
\hline Cystic & 24 & 92.3 & 2 & 7.7 & & \\
\hline Mixed & 57 & 87.7 & 8 & 12.3 & & \\
\hline \multicolumn{7}{|l|}{ Echogenecity } \\
\hline Нypo & 61 & 70.9 & 25 & 29.1 & \multirow{3}{*}{11.30} & \multirow{3}{*}{0.004} \\
\hline Hyper & 17 & 85.0 & 3 & 15.0 & & \\
\hline Iso & 42 & 95,5 & 2 & 4,5 & & \\
\hline \multicolumn{7}{|l|}{ Margins } \\
\hline Well defined & 114 & 83,8 & 22 & 16,2 & \multirow{2}{*}{13.31} & \multirow{2}{*}{0.0003} \\
\hline Ill defined & 6 & 42,9 & 8 & 57,1 & & \\
\hline \multicolumn{7}{|l|}{ Calcification } \\
\hline Coarse & 30 & 66.7 & 15 & 33.3 & \multirow{2}{*}{10.94} & \multirow{2}{*}{0.0009} \\
\hline Micro & 3 & 16.7 & 15 & 83.3 & & \\
\hline \multicolumn{7}{|l|}{ Intra-nodular vascularity } \\
\hline Increased & 16 & 57.1 & 12 & 42.9 & \multirow{3}{*}{11.66} & \multirow{3}{*}{0.003} \\
\hline Normal & 101 & 84.9 & 18 & 15.1 & & \\
\hline Decreased & 3 & 100.0 & 0 & 0.0 & & \\
\hline \multicolumn{7}{|l|}{ Size } \\
\hline$<2 \mathrm{~cm}$ & 36 & 67.9 & 17 & 32.1 & \multirow{3}{*}{7.617} & \multirow{3}{*}{0.002} \\
\hline $2-4 \mathrm{~cm}$ & 57 & 87.8 & 8 & 12.3 & & \\
\hline$>4 \mathrm{~cm}$ & 27 & 84.4 & 5 & 15.6 & & \\
\hline Enlarged Lymph nodes & 39 & 76.5 & 12 & 23.5 & & 0.5 \\
\hline
\end{tabular}


Table 4 - Fine needle aspiration results according to Bethesda system.

\begin{tabular}{|c|c|c|c|c|c|c|}
\hline \multirow{3}{*}{$\begin{array}{c}\text { FNAC } \\
\text { (Bethesda groups) }\end{array}$} & \multicolumn{4}{|c|}{ Histopathology } & \multirow{3}{*}{$\chi^{2}$} & \multirow{3}{*}{$p$-value } \\
\hline & \multicolumn{2}{|c|}{ Benign } & \multicolumn{2}{|c|}{ Malignant } & & \\
\hline & $N$ & $\%$ & $\mathrm{~N}$ & $\%$ & & \\
\hline I & 5 & 100.0 & 0 & 0.0 & \multirow{6}{*}{99.97} & \multirow{6}{*}{$<0.001$} \\
\hline ॥ & 89 & 98.9 & 1 & 1.1 & & \\
\hline III & 16 & 88.9 & 2 & 11.1 & & \\
\hline IV & 6 & 66.7 & 3 & 33.3 & & \\
\hline V & 2 & 28.6 & 5 & 71.4 & & \\
\hline VI & 2 & 9.5 & 19 & 90.5 & & \\
\hline
\end{tabular}

\section{DISCUSSION}

Thyroid nodules are a common clinical problem. Epidemiologic studies have shown the prevalence of palpable thyroid nodules to be approximately $5 \%$ in women and $1 \%$ in men living in iodine-sufficient parts of the world. In addition, high resolution ultrasound (US) can detect thyroid nodules in 19-67\% of randomly selected individuals with higher frequency in women and elderly ${ }^{12}$.

Clinically there are simple characteristics that are known to be risky regarding malignancy including male sex, age below 30 y and above 60y, family history of previous thyroid malignancy, previous exposure to neck irradiation and a hard nodule that may cause compression symptoms ${ }^{5}$. The most prevalent types of thyroid malignancies are the differentiated types, papillary and follicular malignancies ${ }^{13,14}$.

In this study out of 150 cases with thyroid nodules there were 83 patients with MNG and 67 with solitary thyroid nodules. Out of 83 patients with MNG, there were 73 patients with benign nodules and only 10 patients with malignant nodules. On the other hand, out of 67 patients with solitary thyroid nodules, there were 20 patients with malignant nodules this denotes that the solitary thyroid nodules is more risky than MNG. Frates et al $(2006)^{8}$, reported that the incidence of malignancy in solitary thyroid nodules is higher than that of MNG $(p<0.01)$. Historically MNG was considered a benign condition with a low risk of malignancy but recent studies reported that the incidence of malignancy 
is equal in both STN and $\mathrm{MNG}^{15}$. The difference in the reported rates of malignancy among patients with STN and MNG in the above studies undoubtedly reflects difference in the selection criteria used for analysis, as well as geographic differences in the population studied $^{16}$.

In the present study. no significant difference in age was found between patients with benign disease and those with malignant disease. The median age was 41 years and 40 years, respectively. Witczac et al (2016), reported similar results which is in accordance with our study ${ }^{18}$. Recent studies reported that most thyroid malignancies occur in the middle age group $20-60 y^{17,18}$.

In this study men had a higher incidence of malignancy than females with a significant difference $(p=0.02)$. A recent study reported similar data with high incidence of malignancy in males ${ }^{19}$. On the other hand, Paul et al (2017) reported that incidence of malignancy is higher in females ${ }^{16}$. Other studies reported that there is no significant difference between both sexes regarding the incidence of malignancy ${ }^{18,20,21}$. However, after combining age to sex the significance was lost suggesting that sex is not a strong independent predictor of malignancy. This difference between studies may be due to geographic differences and the number of population studied.

In our study only 13 patients recorded as smokers with three patients had malignant nodules all of them were males with no statistical value. Other study reported that smoking decreases the risk of papillary carcinoma through increasing sympathetic discharge and increase in T3, T4 levels and accordingly decrease in TSH levels which is a risk factor in papillary carcinoma 22 .

Though history of previous radiation exposure and presence of family history of thyroid cancer are well established thyroid cancer risk factors that even affect the decision for FNA biopsy of thyroid nodule more than the nodule size itself ${ }^{12,21}$. No significant difference could be detected regarding family history of thyroid cancer. previous radiation exposure. or history of previous thyroid surgery in the present study. None of the patients in this study had hoarseness of voice. Some patients had dysphagia, dyspnea with no statistically significant value. 
The imaging modality of choice for the investigation of thyroid nodule is high resolution US, which has been proven to be an important, cost-effective, simple, safe and accurate method for triaging patients with thyroid nodules either to surgical intervention or follow-up ${ }^{23}$.

In this study out of 30 cases with macro-calcifications 15 cases were malignant and 15 cases were benign and out of 18 cases with micro-calcifications there were 15 cases with malignant nodules and only 3 cases with benign nodules on the final histopathology reports with high significant value of micro-calcification in predicting malignancy in thyroid nodules $(P=0.0009)$. Many studies reported that micro-calcifications are considered as an independent predictor of malignancy in thyroid nodules ${ }^{7,17,19,20}$. In this study, ill-defined edges were statistically significant in predicting malignancy. Similar results were reported in literature ${ }^{17,19,20}$.

Out of 30 cases with malignant thyroid nodules there were 25 cases with hypoechoic pattern $(p=0.004)$. Paul et al $(2017)$, reported that hypo-echoic nodules were seen in $82 \%$ of malignant cases ${ }^{16}$. Other studies reported similar data ${ }^{8.24}$. On the other hand, Jaheen et al (2017), found that hypo-echoic pattern is not significant in predicting malignancy ${ }^{19}$.

Intra-nodular hyper-vascularity is known to be a risk factor for malignancy in patients with thyroid nodules and reported by several others ${ }^{12,24,25}$. In this study the increased intra-nodular vascularity was a significant predictor of malignancy $(P=0.003)$. Jaheen et al (2017), reported that increased peri-nodular vascularity is more significant predictor of malignancy than intra-nodular vascularity ${ }^{19}$.

Solid composition of thyroid nodules was significant in the current study $(p=0.006)$. Many studies reported similar results $7,17,19,20$. However, a study by Macias et al (2015) reported that the solid nature of the thyroid nodule is not significant predictor of malignancy ${ }^{26}$.

In the current study the size of nodules below $2 \mathrm{~cm}$ was statistically significant in predicting malignancy. Cavallo et al (2017), reported that the risk of malignancy is inversely 
related to the nodule size ${ }^{27,28}$. Other studies reported that larger nodules are more liable to have malignancy than smaller nodules ${ }^{7,27,29}$.

In the current study, out of 150 patients there were 51 patients with enlarged lymph nodes 12 of them were malignant in the final histopathology reports with nonsignificant $p$-value $(p=0.5)$. Other studies reported the significance of enlarged lymph nodes as a predictor of malignancy in thyroid nodules ${ }^{20,24}$. On the other hand Paul et al, (2017), reported that enlargement of lymph nodes are of low value in predicting malignancy in thyroid nodules ${ }^{16}$.

Fine needle aspiration (FNA) has an essential role in the evaluation of euthyroid patients with thyroid nodule(s). It reduces the rate of unnecessary major thyroid surgery for patients with benign nodules and triages patients with thyroid cancer to appropriate surgery $^{30}$. In the present study, 5 (3\%) patients were classified as $\mathrm{BI}$ (non-diagnostic or unsatisfactory), which fits in the recommended incidence rate of $\mathrm{BI}$ ranging from 2 to $20 \%$, and ideally should be limited to no more than $10 \% 30$. The incidence of malignancy in $\mathrm{BI}$ was $0 \%$, many previous studies reported range of malignancy incidence between 1-4 $\%^{12,23,30}$. This difference may be due to not all reports made by the same pathologist and not all smears were ultrasound guided. In Bll there were 89 patients only one had malignant nodules with $1.1 \%$ false negative. The reported false negative rate in literature is low (0-3\%) and may reach up to $5 \%$ being higher with large nodule $(\geq 4 \mathrm{~cm}$ ) and this matches with the current study results ${ }^{12,31}$.

There were 18 patients in BIII with 2 (11\%) cases had malignant nodules. Other studies reported higher incidence $16-40 \%^{20,32}$. There were 9 patients in BIV with 3 (33\%) cases proved to have malignant nodules. The average reported rate of BIV was $17 \%$ with a range of $1.2 \%-25.3 \%$, with malignancy rate of $26 \% 33$.

The suggested risk of malignancy in BV is 60-75\% (30). In this study there were 7 cases in BV with 5 (71\%) cases had malignant nodules. Jaheen et al (2016), reported similar results with incidence of malignancy in $51 \%$ of cases belonging to $\mathrm{BV}^{19}$.

Regarding BVI there were 21 cases in this group with 19 cases had malignant nodules (PPV 90.5\%) with false positive rate of (9.5\%). In general, false positive results of 
BVI in MNG patients, in the literature, found to be ranging from $0.5 \%$ to $10 \%{ }^{33}$. Similar result was reported by Jaheen et al (2016). It is remarkable that there were a gradual increase in incidence of malignancy from BII-BVI, with the highest incidence in BVI making this group statistically significant in predicting malignancy in thyroid nodules ${ }^{19}$.

\section{CONCLUSION}

There are significant predictors of malignancy in thyroid nodules such as: male gender. solitary nodules. size below $2 \mathrm{~cm}$, micro-calcifications, hypo-echogenic pattern, solid nodules, ill-defined edges and increased intra-nodular vascularity. This will help clinicians to spare more benign cases from surgical interference.

\section{REFERENCES}

1. Ashcrft MW, Van Herle A J. Management of thyroid nodules. II: Scanning techniques, thyroid suppressive therapy, and fine needle aspiration. Head Neck Surg. 1981;3(4):297322.

2. Frates MC, Benson CB, Charboneau JW, Cibas ES. Clark OH. Coleman BG, et al. Management of thyroid nodules detected at US: Society of Radiologists in Ultrasound consensus Conference Statement. Radiology. 2005; 237(3);794-800.

3. Monson JP. The epidemiology of endocrine tumours. Endocr Relat Cancer. 2000;7:2936.

4. Vigneri R, Maladrino P, Vigneri P. The changing epidemiology of thyroid cancer: why is incidence increasing? Curr Opin Oncol. 2015;27:1-7.

5. Hegedüs L. The thyroid nodule. N EngI J Med. 2004;351:1764-71.

6. Nachiappan AC, Metwalli ZA, Hailey BS, Patel RA, Ostrowski ML, Wynne DM, et al. The thyroid. Review of imaging features and biopsy techniques with radiologic-pathologic correlation. Radiographics. 2014; 34:276-93.

7. Smith-Bindman R, Miglioretti DL, Johnson E, et al. Use of diagnostic imaging studies and associated radiation exposure for patients enrolled in large integrated health care systems, 1996-2010. JAMA. 201213;307(22):2400-9.

8. Frates $\mathrm{MC}$, Benson $\mathrm{CB}$, Doubilet $\mathrm{PM}$, Kunreuther $\mathrm{E}$, Contreras $\mathrm{M}$, Cibas ES, et al. Prevalence and distribution of carcinoma in patients with solitary and multiple thyroid nodules on sonography. J Clin Endocrinol Metab. 2006;91:3411-7.

9. Chow LS GH, Goellner JR, van Heerden JA. Non diagnostic thyroid fine-needle aspiration cytology: management dilemmas. Thyroid. 2001; 11:1147-51. 
10. Fiore E, Vitti P. Serum TSH and risk of papillary thyroid cancer in nodular thyroid disease. J Clin Endocrinol Metab. 2012;97:1134-45.

11. Boelaert K, Horacek J, Holder RL, Watkinson JC, Sheppard MC, Franklyn JA. Serum thyrotropin concentration as a novel predictor of malignancy in thyroid nodules investigated by fine-needle aspiration. J Clin Endocrinol Metab. 2006;91:4295-301.

12. Cooper DS, Doherty GM, Haugen BR, Kloos RT, Lee SL, Mandel SJ, et al. Revised American Thyroid Association management guidelines for patients with thyroid nodules and differentiated thyroid cancer. Thyroid. 2009;19(11):1167-214.

13. Townsend CM, Evers BM, Beauchamp RD, Mattox KL. Sabiston textbook of surgery 20th(edn): Canada/Elsevier; 2017.881-940.

14. Luo J, McManus C, Chen H, Sippel RS. Are there predictors of malignancy in patients with multinodular goiter? J Surg Res. 2012;174(2):207-10.

15. Tollin SR, Mery GM, Jelveh N, Fallon EF, Mikhail M, Blumenfeld W, et al. The use of fine-needle aspiration biopsy under ultrasound guidance to assess the risk of malignancy in patients with a multinodular goiter. Thyroid. 2000;10(3):235-41.

16. Paul P, Ali KA, Jasir M. Predictors of malignancy in solitary nodule thyroid. Int Surg J. 2017;4:703-8.

17. Jang J, Keon H, Seo M, Kang J, Cho J, Kim H, Kim I. The effects of patients' sex, age and thyroid-stimulating hormone on malignancy rate of thyroid nodules. Korean J Fam Pract. 2017;7(1):20-24.

18. Witczac J, Taylor P, Chai J, Amphlett B, Soukias J, Das G, et al. Predicting malignancy in thyroid nodules: feasibility of a predictive model integrating clinical, biochemical, and ultrasound characteristics. Thyroid Res. (2016) 9:4.

19. Jaheen $H$, Sakr M. Predictors of malignancy in patients with solitary and multiple thyroid nodules. J Surg. 2016; 12(3):105-10.

20. Papini E, Guglielmi R, Bianchini A, Crescenzi A, Taccogna S, Nardi F, et al. Risk of malignancy in non palpable thyroid nodules: predictive value of ultrasound and colorDoppler features. J Clin Endocrinol Metab. 2002;87(5):1941-6.

21. Wiersinga W. Smoking and thyroid. Clinical endocrinology. 2013;79(2).145-51.

22. Gharib H, Papini E,Paschke R, Duick DS, Valcavi R, Hegedus L, et al. American Association of Clinical Endocrinologists. Associazione Medici Endocrinologi, and European Thyroid Association medical guidelines for clinical practice for the diagnosis and management of thyroid nodules: executive summary of recommendations. J Endocrinol Invest. 2010;33(5 Suppl):51-6.

23. Anuradha Kapali, Jaipal B R, Raghuram P, Ravindra Bangar, Sateesh Kumar Atmakuri. Role of ultrasonogra-phy in thyroid nodules with pathological correlation. Int J Contemp Med Res 2016;3(5):1451-3.

24. Mandel SJ. Diagnostic use of ultrasonography in patients with nodular thyroid disease. Endocr Pract. 2004;10(3):246-52. 
25. Moon WJ, Jung SL, Lee JH, Na DG, Baek JH, Lee YH, et al. Benign and malignant thyroid nodules: US differentiation--multicenter retrospective study. Radiology. 2008;247(3):76270.

26. Macias C, Arumugam D, Arlow R, Eng O, Lu S, Javidian P, et al. A Risk model to determine surgical treatment in patients with thyroid nodules with interminante cytology. Ann Surg Oncol. 2015;22:1527-32.

27. Cavallo A, Johnson DN, White MG, Siddiqui S, Antic T, Mathew M, Grogan RH, Angelos $P$, Kaplan EL, Cipriani NA. Throid nodule size at ultrasound as apredictor of malignancy and final pathologic size. Thyroid. 2017;27(5):641-650 .

28. Cappelli C, Castellano M, Pirola I, Cumetti D, Agosti B, Gandossi E, Agabiti Rosei E. The predictive value of ultrasound findings in the management of thyroid nodules. QJM. 2007;100(1):29-35.

29. Cibas ES, Ali SZ. The Bethesda System for Reporting Thyroid Cytopathology. Thyroid. 2009;19(11):1159-65.

30. Ylagan LR, Farkas T, Dehner LP. Fine needle aspiration of the thyroid: a cytohistologic correlation and study of discrepant cases. Thyroid. 2004;14(1):35-41.

31. Garg S, Naik LP, Kothari KS, Fernandes GC, Agnihotri MA, Gokhale JC. Evaluation of thyroid nodules classified as Bethesda category III on FNAC. J Cytol. 2017;34:5-9.

32. Bongiovanni M, Spitale A, Faquin WC, Mazzucchelli L, Baloch ZW. The Bethesda System for Reporting Thyroid Cytopathology: a meta-analysis. Acta Cytol. 2012;56(4):333-9.

33. Rios A, Rodriguez JM, Galindo PJ, Montoya M, Tebar FJ, Sola J, et al. Utility of fineneedle aspiration for diagnosis of carcinoma associated with multinodular goitre. Clin Endocrinol. 2004;61(6):732-7. 